\title{
1. Introduction to city and regional leadership
}

\author{
Markku Sotarauta and Andrew Beer
}

\section{LEADERSHIP - NOT AGAIN...?}

People - individuals, households and communities - are once again emerging as a focus within local and regional development studies, not only as units that underpin aggregate measures or elements in systems but as deliberative actors with ambitions, desires, strategies and objectives. In this handbook, people continue creeping into the urban and regional development debates from the perspective of leadership.

Yes, it is leadership again. Research on place leadership has the potential to shed light not only on leadership in cities and regions or processes of it or its significance but, as Sotarauta, Beer and Gibney (2017) argue, also on many classic as well as emerging sub-national development issues. It focuses our attention on movement, influence, people and their relationships by linking agency and context to each other within the framework of city and regional development.

\section{A Moving Target}

Broadly speaking, leadership is a challenging subject of study. We can only agree with Keith Grint (2005a) that leadership is an essentially contested concept with multiple possible interpretations and definitions. Leadership is a many-faced creature as all of us have some notion of what good leadership is like, or what the basic features of bad leadership are. These notions emerge from media and our own experiences as leaders and followers and are flavoured by often-heated debates about well-known figures such as Winston Churchill, Adolf Hitler, Barack Obama and Donald Trump, to name a few. Sometimes we praise our heroes; sometimes we attack the ones we see as villains, dragging them down from the podium.

The practice of leading, or the study of it, is not a static target. Research on leadership has experienced both rejuvenation and metamorphosis over the past 40 years. Prior to the early 1980s, leadership as a field of study was in a stalemate, theory development had reached its limit, or so it seemed, and increasingly more it was asked whether leadership even matters, whether it was worth studying (Boal and Hooijberg 2000). Since then, research on leadership has moved on to emphasise the more strategic types of leadership instead of paying most attention to individual leaders or the processes of control and command and supervisory styles of leadership (House and Aditya 1997). For example, strategic leadership (e.g. Finkelstein, Hambrick and Cannella 1996), transformational leadership (e.g. Bass 1985), and 
visionary leadership (e.g. Nanus 1992) have assumed an established place, to varying degrees, both on scholarly agendas and organisational discourses.

Definitions of leadership often address the nature of influence and the roles of actors who are defined as leaders. Researchers define leadership in terms of group process, traits or behaviours or as an instrument of goal achievement (see Bass and Bass 2009 for an extensive review). For us, leadership is essentially about constituting a process of facilitating individual and collective efforts to find the future - to construct a shared purpose as well as to construct, learn about and accomplish shared ambitions. We follow those who differentiate leadership from management by stating that management is more about executing goals and fine-tuning organisational behaviour, and thus its focus is on routines and the predictable. By contrast, leadership is more concerned with influence, the search for novel purposes and boosting transformation. Leadership is concerned with the novel and the unpredictable, while management seeks to achieve the visible and predictable (e.g. Bass 1985; Zaleznik 2004).

In local and regional development, the concepts of management and leadership are not as commonly used in this way, but we could see a similar distinction emerging when contrasting government and policy on one hand and entrepreneurship and leadership on the other, with the two grounded in different forms of authority and power. In the fields of city and regional development, there is an endless stream of problems that need to be solved, ranging from administrative challenges through to structural shocks to social difficulties to ecological adaptations to economic concerns. This is what governments are designed for; they are supposed to work to relate analysis and potential solutions to a specific place and situation, while true leaders mobilise their resources and ambition in search of an as-yet-unknown future. As Grint phrases it, managers have seen it before, and thus the processes of management/government are the equivalent of déjà $v u$. Leadership, for its part, has not, and thus it is the equivalent of vu jàdé (never seen this before) (Grint 2005b, citing Weick 1993).

Future orientation, unpredictability, ambiguity and uncertainty are defining features of place leadership; in part, to understand place leadership is to understand how actors cope with and direct open-ended, multi-actor and potentially conflicted development processes.

\section{Place Leadership at the Intersection of Intentions}

New research results on place leadership are being published in a continuous stream (see Beer, Sotarauta and Ayles, Chapter 2 in this handbook), but there is a growing demand to do even more. For a long time, leadership was a missing piece in the city and regional development puzzle (Rodríguez-Pose 2013). We approach city and regional leadership by using the notion of 'place leadership' as an umbrella concept, capturing many conceptualisations (see below). Earlier studies have shown that place leadership as a specific form of leadership exists; place leaders indeed have the capacity to influence others, and place leadership matters to the economic development of places. Nicholds et al. (2017) conclude that it is possible to cultivate multilevel and 
shared leadership for a place, leadership attuned to political strategies and aimed at balancing power among competing vested interests and relying on communication, negotiation and the management of broad sets of relationships. Leadership may even be a decisive ingredient in tailoring strategies to serve the specificities of place (Beer 2014). It directs but does not determine outcomes (Beer et al. 2019).

To be able to make a difference, place leaders need to act at the intersection of different intentions, interests and aims, identifying and using a range of influence tactics for varying situations. We indeed need to know more about how, for the development of cities and regions, strategic decisions are reached; how visions guiding shared activity emerge or are constructed as well as communicated; how place-specific networks and ways of organising are constructed, organised and directed. Place leadership occurs in an environment embedded, as said, with ambiguity, complexity and information overload as well as a variety of conflicting, as well as converging, views on what should be done and how in each place. In this kind of environment, as Blažek et al. (2013) observed, results can be achieved only if the key actors are wholly committed to working towards change or, as they argued further, if the entire system is set into motion in a desirable direction and if the leadership and development work is not hampered by structural or institutional issues. Hu and Hassink argued along the same lines, contending that place leadership does not produce short-term effects as it works through "influencing and shaping institutions as "mediators" of economic practice and interaction' (Hu and Hassink 2017, 232).

Research on place leadership, focused on people and development processes, has the potential to reveal the muddled nature of regional development and the many tensions that arise when multiple ambitions and rationalities collide. As Sotarauta (Chapter 9 in this handbook) maintains, "place leadership operates on the one hand in between the intentions of placeless actors and unpredictable economic-social-political forces, and on the other hand, amidst a variety of place-based needs and intentions. Each of these sources of pressure is not one-dimensional but actually notoriously multi-dimensional and complex' (see Figure 1.1).

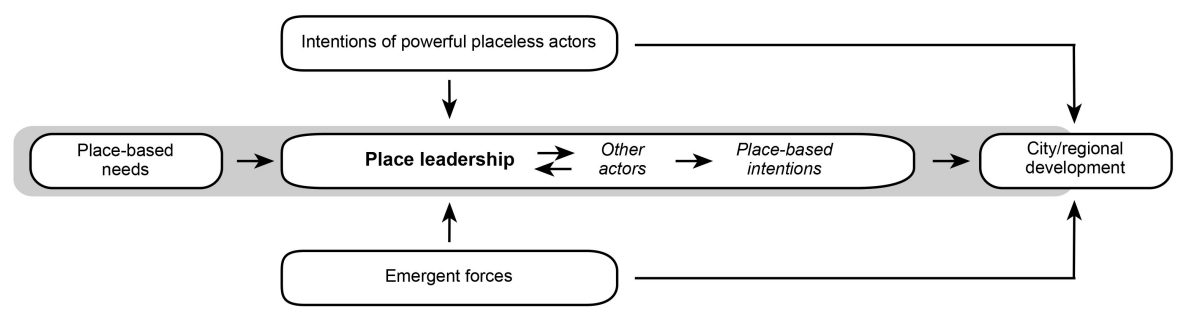

Figure 1.1 The position of place leadership in between place-based needs, intentions of placeless actors and emergent forces 
By definition, place leadership is not about contented individuals working in harmony towards common goals. The reality is often far from it. At its best, research on place leadership identifies the elements and core processes of well-functioning micro-level practices that have the potential to influence sets of actors and move them in harmony and in this way to produce desirable outcomes. But, research on place leadership has the potential to reveal the patterns of toxic leadership, too, corrupt patterns of influence or mis-placed judgements. Moreover, it is important to stress that even the best practices of place leadership do not somehow automatically generate improved local and/or regional performance. It would be almost impossible to make simple correlations between place leadership and visible outcomes in a given place. At least at this point of development, it is fairly impossible to measure empirically everything that leaders are expected to achieve or are claimed to have achieved. Place leadership studies are always at risk of being compromised by retrospective analyses that introduce causal links between improved performance and 'skilful leadership'.

\section{The Context}

Place leadership is about the mobilisation of key resources, competencies and powers; we see mobilisation as one of the core concepts in place leadership. If there is no mobilisation for city and regional development, there would be no leaders or followers, either. Relatedly, to a greater or lesser degree, all leadership studies set in a sub-national context show that leadership is more relational and collaborative rather than heroic and individualistic (Hambleton 2015: see Beer, Sotarauta and Ayles, Chapter 2 in this handbook). Indeed, mobilisation and influence take place in the midst of ambiguous situations, which are characterised by governance systems, structures and social connections typical of a place. Importantly, place leadership is fundamentally shaped by context and works according to the context, that is, it responds to and seeks to influence the circumstances of that place.

In any study on place leadership, it is crucial to understand its relationship with governance, economic and geographical structures. The highly relational and contextual nature of place leadership makes it a unique target of study among other forms of leadership study. Of course, all this is relative in itself as organisational and political leadership scholars also acknowledge the importance of relationality and a context but place leadership as a form of enquiry embedded in geography and regional studies adopt context as one of the core targets of attention. The circumstances shaping a region, a city, a town or a small rural community determine the capacity for leadership to emerge and shape the ways in which it is expressed (Beer 2014), hence patterns of leadership may differ from place to place, within a country and between countries with respect to the style, impact and aspirations of leaders (Kroehn, Maude and Beer 2010; Hidle and Normann 2013; Blažek et al. 2013; Sotarauta, Kurikka and Kolehmainen, Chapter 12 in this handbook; Beer et al. 2019). However, earlier studies have shown, in spite of visible differences between places, there are similarities between different places and spatial scales, too. When comparing place leadership in six countries, Beer et al. (2019) found meaningful similarities in relation to 
the central role of boundary spanning. They found overall stereotypical approaches to place leadership in each locality (Beer et al. 2019).

Context greatly affects the capacity place leaders have to manoeuvre. Based on their study of five European city-regions, Budd et al. (2017), in line with other studies, saw context as an essential parameter in the comparative analysis of leadership. In their analysis, the patterns of leadership included a number of common features in spite of the differing contexts, including the roles of political leaders, tensions between political and civic leadership and the intermediary role of managerial leadership. Budd et al. concluded that the influence of context on place leadership is contingent; it may or may not influence place leadership patterns (Budd et al. 2017). Hidle and Normann (2013) showed how much leadership patterns may differ between two cities in one country, specifically between the two Norwegian cities of Kristiansand and Stavanger. According to them, leadership is anchored outside the representative political system in Kristiansand and inside of it in Stavanger. They highlighted the importance of studying how power is institutionalised in order to understand leadership processes as where power is set in a regime, it shapes not only regional economic development but also the qualities of local democracy. On their part, Bailey et al. (2010) revealed how different types of local production systems give birth to differing leadership patterns, leading to either incremental or structural and radical changes (Bailey et al. 2010). Moreover, as Blažek et al. (2013, 282-283) argued, 'the lack of a proactive approach at the national level creates a great deal of room for the initiatives of regional actors. Regional actors' use of this space for bottom up approaches is by no means automatic; it is conditioned by both structural and soft factors, such as leadership'.

In sum, the research on place leadership is deeply embedded in regional studies, and thus most of the empirical studies deal with contexts. Place leadership scholars share the view that the patterns of place leadership are contingent on broader environmental factors, especially governance, economic drivers and social structures. Consequently, to understand place leadership is to understand the context in which it is practiced. But, as Grint (2005b, 1470-1471) importantly maintains (see also Sotarauta and Pulkkinen 2011; Grillitsch, Rekers and Sotarauta, Chapter 17 in this handbook):

[the assumption of the importance of context] underestimates the extent to which the context or situation is actively constructed by the leader, leaders, and/or decision-makers. In effect, leadership involves the social construction of the context that both legitimates a particular form of action and constitutes the world in the process. If that rendering of the context is successful - for there are usually contending and competing renditions - the newly constituted context then limits the alternatives available such that those involved begin to act differently. Or to put it another way, we might begin to consider not what is the situation, but how it is situated. 


\section{Who are They?}

Regions and cities need leaders who have the ability to influence people to see and reach beyond routines to break away from past experiences and development paths. They need actors that are capable of using their power to mobilise resources and networks to these ends, thereby assuming a leadership position for the creation of a collective meaning which potentially leads to a new development agenda (Normann et al. 2017). But who are they? Crucially, as Selznick $(2011,24)$ argued: 'leadership is not equivalent to office-holding or high prestige or authority or decision-making. It is not helpful to identify leadership with whatever is done by people in high places'. Indeed, place leadership may be assumed by different types of actors. We need to know more about who influences other actors, and how and why, in aiming to make the places we live in better and how organisational imperatives or political ambitions shape their behaviours.

The research has shown, in many places, the importance of professional and political leadership in place leadership but also that a wide-ranging pattern of place leadership is possible. Therefore, we do not want to prescribe who the place leaders are, and, even more importantly, we do not set out who they should be. Similarly, we are very hesitant to say what the correct leadership strategies and influence tactics are. We underscore the importance of an open mind and empirical research in the identification of place leadership patterns. Following and complementing Hambleton (2015) and Hartley (2002), we identify five actor types that may potentially, independently or in some combination make up the concept of place leadership.

- Managerial actors: public managers and leaders working in government organisations

- Political actors: local politicians and potentially also politicians from other governance levels

- Civic actors: actors from non-governmental and other civic organisations

- Academic actors: actors working in the higher-education sector

- Business actors: actors working for businesses of different size.

What we know is that place leadership may have many manifestations. For example, Blažek et al. (2013) showed, based on their empirical study in Czechia, in different regions, that place leadership roles may be taken on by different types of actors. Similarly, Sotarauta, Kurikka and Kolehmainen (Chapter 12 in this handbook) identified a business community assuming a leading position in one Finnish sub-region, while in another, a few key public organisations and individuals assumed a similar position. According to Horlings et al. (2018), in rural areas, both public, private and civic actors may play a leadership role. But, place leadership does not appear by default; it is an open question as to who is able to bridge vested interests and broker new connections while also removing obstacles blocking communication. Nonetheless, these leaders need the capability set that enables them to initiate a process of shared reflection while igniting a collaborative spirit that defines their 
Table $1.1 \quad$ Formal and informal/assigned and non-assigned place leadership with illustrative examples from Finland based on empirical studies

\begin{tabular}{lll}
\hline & Assigned & Non-assigned \\
\hline Formal & $\bullet$ Influential actors having a legitimised position & $\bullet$ Influential actors having a legitimised position \\
authority & in a public, corporate or some other governance & in a governance system but no obligation to \\
& system and an obligation to work for local and & work for a place and boost its development \\
& regional development & \\
& $\bullet$ Most commonly, managerial and political actors & CEO of a Chamber of Commerce \\
& such as mayors, chief executives in municipali- & \\
& ties and directors of regional councils as well as & \\
chairpersons of local and regional councils & \\
Informal & $\bullet$ Champions of civic and voluntary organisations & $\bullet$ Actors without a legitimised position in a gov- \\
authority & with proclaimed objectives to shape local/ & ernance system and no obligation to work for \\
& regional development & a place and boost its development; for example: \\
& & $\bullet$ individual entrepreneurs \\
& & $\bullet$ individual professors \\
& & $\bullet$ civic activists \\
\hline
\end{tabular}

Note: It is important to note that the formal/informal authority is in relation to the issue in question. Source: $\quad$ Sotarauta and Beer (2017); Beer et al. (2019).

leadership (Horlings et al. 2018). We also need to learn more about how, why and where the next generation of place leaders has the opportunity to learn that art.

As the scholarship presented in this handbook demonstrates, being a place leader is not a position, but a role assumed or provided by others. Place leaders are those who work for a place in a collective space and/or work to create that space. They may be leaders in their own fields of operation or organisations but not necessarily so. Place leadership may also emerge outside established leadership cadres. Vallance, Tewdwr-Jones and Kempton $(2019,1723)$ show how 'actors can mobilize interpretive and network forms of power outside formal governance structures to encourage long-term thinking and broker innovative cross-organizational projects'. Importantly, they also remind us that informal leadership is dependent on local institutional and resource authorities. Place leadership may draw on informal or formal authority, and one of the core questions in place leadership is to scrutinise how informal and formal domains of authority interact (see Potluka, Chapter 6 in this handbook). Formal leadership refers to influential actors having an officially recognised position in a governance system, while informal refers to influential actors influencing others in spite of the fact that they do not have a formally designated or codified position.

Relatedly, as Sotarauta (2016) argued, it is also important to differentiate between assigned and non-assigned leaders (see Table 1.1). As he defined, assigned leaders are granted the authority to exercise power on behalf of some collective to work for a place, while non-assigned leaders gain their leadership position without having formal power because of the ways other people respond to them. Non-assigned leaders seize the power in spite of their lack of institutional and/or resource power. 
To become a place leader, a formal leader with an assignment needs to aim to influence actors beyond the formal delegation and responsibilities but use the power and resources they possess, as a consequence of their formal position, to achieve a wider impact through, with and by other actors. In other words, they do what they are supposed to do, but they also consciously aim to reach beyond their authorisation.

\section{A DEAR CHILD WITH MANY NAMES}

This book is entitled Handbook on City and Regional Leadership. We could have, however, also called it a handbook on place leadership or territorial leadership or local leadership, for example. All these would have been fine in their ways. Many concepts have been used to study leadership in a sub-national context. The conceptualisations overlap in many ways and are often used interchangeably; they are used referring to both different and similar patterns of leadership. Having read through the core literature, carrying out an extensive review on place leadership (Beer, Sotarauta and Ayles, Chapter 2 in this handbook) and drawing on our experience in researching leadership, we use 'place leadership' (place-based leadership) as an umbrella for all different types of leadership in the disciplinary context of regional studies and human geography. Place leadership may be specified, whenever needed, with a more precise concept, such as 'city', 'rural', 'territorial', 'community' and so forth.

The concepts of place and region are scalable, overlapping in many ways (Entrikin 2018). But, they are on many dimensions more nested than parallel. Place is a scalable concept allowing us, first, to discuss the general features of leadership that cross many territorial scales and, second, to integrate human beings more directly into otherwise fairly structural concepts. Significantly, 'place' adds a human dimension and focus to studies of sub-national phenomena more directly than 'region' as it emphasises human experience and subjective views on development and change (Agnew 2011). This is critical for research on place leadership because it speaks to the motivations of individuals and groups. It draws our attention to a specific location, its institutional settings and the meanings it holds for people. Place mediates physical, social and economic processes in a geographical context by involving a sense of belonging, a sense of presence and of being in an environment (Entrikin 2018, 48). Drawing on Creswell (2004), Collinge, Gibney and Mabey (2011) suggest that the concept of place includes the following three dimensions:

- location - the fixed geographical coordinates of a physical location

- locale - the material settings for social relations

- sense of place - the subjective emotional attachment people have to places they inhabit.

In sum, regions are cultural, administrative and/or functional contexts where people live, play and work. The concept of place adds people's emotional attachment to any discussion. There is no need or space to discuss the concepts of place and region or 
city in depth here as Paasi, Harrison and Jones (2018) have provided a comprehensive view. In any event, we see place leadership, in general terms, as activities giving a purpose, or as activities searching for a shared purpose for a place and its people. Place leadership is thus about boosting an uplifted sense of a place; it encompasses an awareness of its development needs and required actions for the future and, thus, moves actors - whether individuals or institutions - from an individual space with narrow interests towards a collective mindset and a focus on the common good. At its best, it is about providing groups of people, living in a place and influencing its development from the outside, shared meaning and guidance on how to work together to advance the wellbeing of that place and not just their individual goals. But, place leadership is not only about place; it needs to be responsive to independent ideologies, capacities and networks (Davies 2009).

\section{KEY QUESTIONS IN A STUDY OF CITY AND REGIONAL LEADERSHIP}

Whatever we think about individual leaders and their capacity to lead, we know all too well that leadership is a real phenomenon and worth exploring in more depth. It is somewhat surprising that no theory of place of leadership in city and regional development has yet surfaced given the fact that there is a long tradition of studying all sorts of sub-national development processes as well as the leadership of nations and organisations. This book is embedded in a conviction that leadership is central to city and regional development, but its definition and enactment call for more work. There clearly is an increasing need to better understand how proactive, but also reactive, and symbolic forms of influence come together in the fields of city and regional development. Moreover, we do not yet know well enough what kind of institutional arrangements push leadership to be more collective than individualistic, more sub-national than national, more networked than siloed or more productive than toxic. Conversely, there is space for future improvements in our understanding of what forms of leadership best shape institutional arrangements for future instead of past needs.

Applying Selznick (2011, 423-424), when studying place leadership, we need to (a) be aware of the relations between actors in a place and external to it; (b) investigate the embedded nature of these relationships, including formal and informal institutional relationships; (c) identify the extent to which place leaders extract value from their networks to facilitate (or frustrate) common goals and (d) study the extent to which both governance and social structures influence patterns of leadership but also to what extent they include cleavages between different factions hampering collective effort. Of course, as Selznick (2011) maintains, the accurate analysis of a complex social reality in which leadership is by definition embedded is fraught with difficulty. The core fundamentals, drawing on Grint (2005c), are: 'is it who leaders are? Is it what leaders achieve? Is it where leaders operate? Is it how leaders get things done?' We would add, is it what the context is like? 
Leadership questions often revolve around persons, results, positions and processes (Grint 2005c). However, importantly - as emphasised earlier - we should not take a normative and prescriptive approach when conducting research on leadership in and of cities and regions. There may be many ways to gain leadership and exercise it. We need to develop more refined analytical frameworks, allowing us to systematically analyse contributions of, and issues and problems related to, place leadership - the ways in which capabilities, resources and powers are mobilised for a place. In these respects, the first set of questions emerging from the above discussion, and summarising it, focuses on the question of who the leaders are. To answer this question, such a methodology is needed that enables a search for leadership through the process instead of the pre-selection of leaders according to their formal positions. The question 'who the leaders are' must be considered as an open empirical question. The second set of questions focuses on the relationship between context and leadership: how do contexts facilitate and/or hamper place leadership, and how do place leaders work to change the very same institutional arrangements in which they are embedded?

All this leads to the third set of questions that revolve around the strategies adopted by leadership and leaders' capacity to lead: how do they aim to accomplish their ambitions; from where do the ambitions emerge; how do they establish new governance and power systems; how do they deploy the existing systems of power and governance as resources in their endeavours; what kinds of power do they have, and how do they exercise influence? The fourth set of questions deals with the soil in which place leaders emerge, operate and learn their skill. More research is needed to establish in what kind of local and regional contexts leadership is possible, including whether there are such local/regional operational cultures that suppress this kind of agency and make it impossible to surface (the four sets of questions are adapted from Sotarauta and Pulkkinen 2011). Essentially, to study place leadership is to study the forces providing direction, convening people and shaping mindsets.

Finally, it is important to acknowledge that the ongoing investigation of city and regional leadership needs to do more than simply seek to further refine and develop its concepts. As a fairly small and still-emerging field, this body of work remains relatively one-dimensional in its analysis of how places are led and where the sources of leadership are to be found. Much of the scholarship to date has been focused on economic questions and, by default, those who tend to occupy the most prominent roles in key organisations and the economy - predominantly males from the mainstream culture. The examination of the leadership of cities and regions will not be complete until it has heard other voices - those of women, minority groups, younger people and those living with a disability. The leadership of these individuals - and their contribution to the lives of many within the community - is as significant as any documented in this handbook. In many instances, this leadership comes from a source and is expressed in ways that are completely invisible to conventional analysis, and we need to recruit both a wider cohort of researchers and engage in methodological innovation if we are to fill this gap. 


\section{THE CHAPTERS}

In this handbook, we argue that deeper critical appreciations of place leadership would provide us with insights into the interplay between, for example, place, power, resources, institutions and policy in specific contexts - and with the aim of shedding light on the questions of why and how, and in whose interest, place leadership is enacted in different places and at different times. These and many other, questions are explored in the following 18 chapters.

Andrew Beer, Markku Sotarauta and Karen Ayles kick the handbook off by providing a systematic review of the academic literature on place leadership in its many territorial and spatial forms (Chapter 2). Their chapter synthesises the emerging body of literature on city and regional leadership into a state-of-the-art view. Beer, Sotarauta and Ayles pinpoint several theoretical and methodological gaps and discuss where this field of study needs to progress to address the major research gaps.

In Chapter 3, Alyson Nicholds sets out a philosophical enquiry on the assumptions underpinning organisational leadership practices to conceptualise and advance our understanding on 'who leaders are and what they do'. She discusses three key historical organisational leadership strands for consideration of, in her own words, "whether leadership ability comprises "who you are" (i.e. your immutable character/ traits), "what you do" (i.e. the behaviour/skills you use to guide others' performance) or "how you act" (i.e. the processes/practices involved)'. Among other things, she argues for rethinking the methodology used in a study of place leadership and developing more discursive accounts of leadership and study of it.

In Chapter 4, Alessandro Sancino, Leslie Budd and Michela Pagani argue that in regional and urban studies, the concept of place leadership challenges the existing theories and conceptualisations 'to acknowledge the role of soft, relational and collective human agency in determining and explaining patterns of economic development in urban and rural areas'. They first discuss and connect the concepts of place leadership, policy-making and politics, and from there they move on to identify four key issues of agency, power, scale and (in)formal spaces. In conclusion, Sancino, Budd and Pagani propose conceptual recommendations and call for more empirical studies investigating the interconnections between place leadership, policy-making and politics. They highlight the importance of political and socio-cultural dimensions in a study of place leadership.

John Gibney and Alyson Nicholds, in Chapter 5, continue where Sancino, Budd and Pagani left off by re-imagining place leadership as social purpose. They agree with the previous chapter that limited attention has been paid to the wider socio-political contexts framing place leadership, and therefore many leadership propositions do not meet the expectations for various leadership endeavours. Therefore, they end up underscoring the importance of adding the concept and idea of social purpose into the many debates on, and empirical studies of, place leadership. Gibney and Nicholds argue, based on their conceptual analysis, that there is a need to rethink the meanings, justifications and practices of place leadership for the development of a more critically reflexive, inclusive and distributed leadership at the sub-national scale. 
Chapter 6 continues Gibney's and Nicholds's line of thinking and reminds us about the importance of informal leadership, that is, voluntary engagement beyond formal political frameworks. Oto Potluka discusses place leadership by focusing on non-profit leadership and civic engagement and compares them to formal place leadership. He introduces a conceptual framework connecting formal and informal leadership with co-creation and co-production. In doing so, Potluka introduces three modes of place leadership, ranging from formal leadership limiting co-production and co-creation to informal leadership working to connect people to production in the public sector. When concluding his chapter, Potluka opens a door for the next chapter by calling for studies focusing also on the business sector and not only on civil society and the public sector.

In Chapter 7, Hans-Hermann Albers and Lech Suwala indeed take up the challenge set by Potluka and discuss place leadership and corporate spatial responsibilities. In doing so, they aim to contribute to a more systematic understanding of the potential for place leadership by private-sector actors. Albers and Suwala ask, drawing on existing case studies focusing on enterprise-driven urban and regional engagement, how place leadership initiatives interact with and contribute to the corporate spatial responsibilities agenda. The corporate spatial responsibilities agenda agrees with the call for place-based economic development strategies and the need to find such modes of operation that provide us with solutions that are not as reliant on state actors as we are used to in many nations. Albers and Suwala argue: 'For the future, it is desirable to explicitly include the private sector in place leadership roundtables in order to create tri-sectoral negotiations. Only then can true transparency, communication, reciprocity and mutual sensitivity for the needs of the counterparts begin to resolve problems'.

Robin Hambleton begins his chapter (8) by maintaining that the many issues confronting leaders arise somewhere else, not only in the same locality or even a country. Thus, there is a need to understand more in-depth place leadership that reaches beyond a place, that is, the ways 'place-based leaders [...] engage with, and influence, the thinking and behaviour of actors who are outside their territory', as Hambleton puts it. He shows how place leaders engage in international activities to draw lessons from their international peers, build international relationships and upgrade their place-based power. Hambleton also reminds us that higher education institutions are well placed to take central roles in enhancing the international performance of place-based leaders who wish to lead 'beyond place'. Hambleton discusses how place leaders may enhance their power base by going beyond the borders of their local playgrounds.

In Chapter 9, Sotarauta takes the baton from Hambleton and continues the place leadership relay by focusing on combinatorial power. First, he argues that the power relationships framing and guiding local development are both constructed through networks and embedded within them, they may be place-based or reach beyond a place. From this premise, he moves to discuss the dynamics of combinatorial power rather than seeing power as a cumulative product or a 'thing'. In his view, 'place leadership is about drawing on, and influencing, power relationships while simulta- 
neously becoming embedded within them'. Therefore, as local and regional development are negotiable as well as ambiguous, diverse and complex, place leaders need to mobilise and coordinate networks by combining different forms of power.

Jiří Blažek and Viktor Květoň's study on the Moravia-Silesia region in Czechia examines the role of leadership in the emergence of a regional innovation system in an old industrial region - how a region is transforming from coal-mining to data-mining (Chapter 10). Blažek and Květoň identify the role of leaders in the process of fundamental socio-economic transformation in a post-socialist country and one of its regions. By rooting their treatise in regional innovation systems, they end up arguing that 'the role of leaders from the public administration as well as from the business sector and academia is undoubtedly crucial in such a venture'. But, importantly, as they show, there is significant variation in the ways public organisations and individual leaders contribute to processes shaping the transformation of a region; as the institutional set up evolves in time, the needs of the region change, and the leadership capabilities are not equally spread among the actors.

Chapter 11 takes, geographically, the discussion of place leadership from Czechia to Italy and, conceptually, from regional innovation systems to industrial districts. Marco Bellandi, Monica Plechero and Erica Santini present a conceptual framework to assess the roles of place leadership in industrial districts by including differing systemic conditions in the analysis. They conclude, based on their empirical evidence, that with cooperative governance and strong place leadership, a positive path transformation has a chance to emerge. Conversely, in a case of vulnerable or fragmented governance, and a weak or enclosed place leadership, change efforts meet resistance locally. Importantly, Bellandi, Plechero and Santini conclude that further research on the negative side of place leadership is needed to open a window to this less discussed, but nonetheless existing, feature of place leadership.

Following the previous three chapters, in Chapter 12, Markku Sotarauta, Heli Kurikka and Jari Kolehmainen continue the analysis of place leadership in the context of economic development by examining it in the peripheral Finnish regions. They ask by whom, and how, local path development is promoted in different types of peripheral regions. Conceptually, Sotarauta, Kurikka and Kolehmainen link place leadership with path development and institutional change. They show how place leadership patterns and development practices differ from each other in two different types of peripheral regions even though they are embedded in the same national governance system. Indeed, development paths shape not only economic development but the patterns of place leadership.

In Chapter 13, Liliana Fonseca, Lisa Nieth, Maria Salomaa and Paul Benneworth focus on the ways universities contribute to innovation and regional development and ask to what extent does the university's institutional architecture affect their regional leadership roles. They, in line with the previous chapters, emphasise the importance of context in how the different leadership roles are assumed. Drawing on case studies in six countries, they examine such contextual factors as regional settings, relationships with regional partners and the internal institutional structure of universities. They conclude that alignment and agency are central in the efforts to understand how 
universities may take leading roles in regions. By alignment, they refer to 'university managers engaging with regional innovation coalitions in ways in which their legitimacy is reinforced by their existing internal activities'. Crucially, alignment is dependent on their grassroots-level actions but potentially also on incentives rewarding or mandating the ways they may take leadership positions.

After four economic development-oriented chapters, Martin Quinn takes us back to where we began this endeavour; place leadership is very much a social and political question, too. In Chapter 14, he discusses place leadership in relation to existing governance structures by using an elected mayor of the City of Leicester as a case in point. He uses social contract theory to shed additional light on how the space for leadership may be constructed. Among other observations, Quinn shows the importance of working across multiple networks to create a sense of shared purpose and of aligning new leadership with existing core processes and successes. All this is temporally embedded, and the windows of opportunity may be open for only a limited amount of time.

Drawing on their literature review, Beer, Sotarauta and Ayles called for studies reaching beyond Anglo-American, Australian and European democratic countries, and Chapter 15, by Sergio Montero and Andrés M. Medina-Garzón, does exactly that. They underscore a conceptualisation of leadership in the context of local economic development by examining how power relations either allow or limit the emergence of leadership in different territorial contexts. Montero and Medina-Garzón, in their own way, connect their chapter not only to the chapters discussing the economic development of places but to those discussing leadership as social purpose, combinatorial power, institutions and politics, too. They advance the idea of inclusive leadership, which is embedded in the inclusion of historically marginalised populations. In this way, they close the conceptual and empirical discussions initiated by the first chapters and carried forward by the following ones. According to Montero and Medina-Garzón, the main ambition of leadership should be 'the promotion of social justice by changing the unequal power relations that characterise the political economy of different geographical contexts', as Gibney and Nicholds also underscored.

Part III of the handbook shifts the attention to methodological questions. Andrew Beer and Jacob Irving build on the notion that the research on place leadership has been more in search of novel conceptual frameworks than the development of new methodological approaches (Chapter 16). They maintain that many methodological avenues have not yet been explored and that, because of this, further conceptual and empirical development may remain at an overly narrow level. From this premise, Beer and Irving set out to explore the broader literature on leadership, including organisational studies and political science, to identify the spaces of methodological development. They not only emphasise the need to tap into a broader set of methods and techniques but also the centrality of mobilising larger programmes of research work, involving significant numbers of scholars combining both quantitative and qualitative approaches. 
The three chapters following Beer and Irving's strong plea for broadening the array of methods applied in place leadership studies aim, each in their own way, to take up the challenge. These chapters do not discuss the pros and cons, or techniques, of existing repertoires but, instead, introduce new ways to study place leadership. Markus Grillitsch, Josephine V. Rekers and Markku Sotarauta (Chapter 17) observe that studies of regional development focus mostly on structural preconditions while agency has remained in the shadows. Agency is both understudied and under-explored. Drawing on their empirical experience from an extensive Nordic research project on the extent to which, and how, actors have shaped regional growth trajectories; they identify and discuss six challenges of a study aiming to investigate the relationship between agency and structure. The challenges include ensuring that the ontology, the research design, the time period, the spatial scale, the research instruments, the data collection and the analysis is right. They demonstrate that the development of novel theoretical frameworks works only if methodological choices support them.

In Chapter 18, based on their extensive experience, James Karlsen and Miren Larrea discuss action research as a methodology to study leadership but also to construct it. In their thinking, action research is both a research methodology and a territorial development strategy. They use the Territorial Development Laboratory of the Provincial Council of Gipuzkoa (Basque Country, Spain) as a case in point. They proceed from the paradigmatic discussion to integrating action research into a cogeneration framework. Karlsen and Larrea live up to the expectations set by Nicholds (Chapter 3) and develop an approach that takes research on place leadership in a discursive direction. Indeed, as they maintain, 'territorial leadership emerges through the agora dialogues'.

Helen Dinmore and Andrew Beer continue the methodological discussion by drawing lessons for policy and place leadership from narrative studies. In Chapter 19 , they explore the capacity of accounts of leadership as a narrative to provide us with fresh perspectives on the leadership of cities and regions. Dinmore and Beer construct their argument through a non-conventional paired case study. On one hand, they draw on a case study on place leadership in Italy and the UK and, on the other hand, a newspaper article on an individual credited with great influence on development in his locality. Interestingly, Dinmore and Beer accentuate how a cultural context in which stories written and read are embedded shapes a layer of meaning, which again frames our interpretations and positioning either to receive or question the values in which the story is rooted.

\section{REFERENCES}

Agnew, J. (2011), 'Space and place', in J. Agnew and D. Livingstone (eds), Handbook of Geographical Knowledge, London: Sage. 
Bailey, D., M. Bellandi, A. Caloffi and L. de Propris (2010), 'Place-renewing leadership: Trajectories of change for mature manufacturing regions in Europe', Policy Studies, 31 (4), 457-474.

Bass, B. (1985), Leadership and Performance Beyond Expectations, New York: Free Press.

Bass, B. M. and R. Bass (2009), The Bass Handbook of Leadership: Theory, Research, and Managerial Applications, 4th edition, London: Free Press.

Beer, A. (2014), 'Leadership and the governance of rural communities', Journal of Rural Studies, 34, 254-262.

Beer, A., S. Ayres, T. Clower, F. Faller, A. Sancino and M. Sotarauta (2019), 'Place leadership and regional economic development: A framework for cross-regional analysis', Regional Studies, 53 (2), 171-182.

Blažek, J., P. Žížalová, P. Rumpel, K. Skokan and P. Chládek (2013), ‘Emerging regional innovation strategies in Central Europe: Institutions and regional leadership in generating strategic outcomes', European Urban and Regional Studies, 20 (2), 275-294.

Boal, K. B. and R. Hooijberg (2000), 'Strategic leadership research: Moving on', The Leadership Quarterly, 11 (4), 515-549.

Budd, L., A. Sancino, M. Pagani, Ó. Kristmundsson, B. Roncevic and M. Steiner (2017), 'Sport as a complex adaptive system for place-based leadership: Comparing five European cities with different administrative and socio-cultural traditions', Local Economy, 32 (4), 316-335.

Collinge, C., J. Gibney and C. Mabey (2011), Leadership and Place, Abingdon: Routledge.

Creswell, T. (2004), Place: A Short Introduction, Oxford: Blackwell.

Davies, A. (2009), 'Understanding local leadership in building the capacity of rural communities in Australia', Geographical Research, 47 (4), 380-389.

Entrikin, N. (2018), 'Geography of experience: Place and region', in A. Paasi, J. Harrison and M. Jones (eds), Handbook on the Geographies of Regions and Territories, Cheltenham, UK and Northampton, MA, USA: Edward Elgar Publishing.

Finkelstein, S., D. Hambrick and A. A. Cannella (1996), Strategic Leadership: Theory and Research on Executives, Top Management Teams, and Boards, St. Paul: West Educational Publishing.

Grint, K. (2005a), Leadership: Classical, Contemporary, and Critical Approaches, Oxford: Oxford University Press.

Grint, K. (2005b), 'Problems, problems, problems: The social construction of "leadership", Human Relations, 58 (11), 1467-1494.

Grint, K. (2005c), Leadership: Limits and Possibilities, Basingstoke, Hampshire: Palgrave Macmillan.

Hambleton, R. (2015), Leading the Inclusive City: Place-based Innovation for a Bounded Planet, Southampton: Policy Press.

Hartley, J. (2002), 'Leading communities: Capabilities and cultures', Leadership \& Organization Development Journal, 23 (8), 419-429.

Hidle, K. and R. H. Normann (2013), 'Who can govern? Comparing network governance leadership in two Norwegian city regions', European Planning Studies, 21 (2), 115-130.

Horlings, L.G., D. Roep and W. Wellbrock (2018), 'The role of leadership in place-based development and building institutional arrangements', Local Economy, 33 (3), 245-268.

House, R. J. and R. N. Aditya (1997), 'The social scientific study of leadership: Quo vadis?', Journal of Management, 23 (3), 409-473.

$\mathrm{Hu}, \mathrm{X}$. and R. Hassink (2017), 'Place leadership with Chinese characteristics? A case study of the Zaozhuang coal-mining region in transition', Regional Studies, 51 (2), 224-234.

Kroehn, M., A. Maude and A. Beer (2010), 'Leadership of place in the rural periphery: Lessons from Australia's agricultural margins', Policy Studies, 31 (4), 491-504.

Nanus, B. (1992), Visionary Leadership: Creating a Compelling Sense of Direction for Your Organization, San Francisco: Jossey-Bass. 
Nicholds, A., J. Gibney, C. Mabey and D. Hart (2017), 'Making sense of variety in place leadership: The case of England's smart cities', Regional Studies, 51 (2), 249-259.

Normann, R. H., H. C. G. Johnsen, J. P. Knudsen, M. Vasström and I. G. Johnsen (2017), 'Emergence of regional leadership: A field approach', Regional Studies, 51 (2), 273-284.

Paasi, A., J. Harrison and M. Jones (2018), 'New consolidate regional geographies', in A. Paasi, J. Harrison and M. Jones (eds), Handbook on the Geographies of Regions and Territories, Cheltenham, UK and Northampton, MA, USA: Edward Elgar Publishing.

Rodríguez-Pose, A. (2013), 'Do institutions matter for regional development?', Regional Studies, 47 (7) 1034-1047.

Selznick, P. (2011), Leadership in Administration: A Sociological Interpretation, digital edition by Quid Pro Books.

Sotarauta, M. (2016), Leadership and the City: Power, Strategy and Networks in the Making of Knowledge Cities, Abingdon, Oxon: Routledge.

Sotarauta, M. and A. Beer (2017), 'Governance, agency and place leadership: Lessons from a cross national analysis', Regional Studies, 51 (2), 210-223.

Sotarauta, M., A. Beer and J. Gibney (2017), 'Making sense of leadership in urban and regional development', Regional Studies, 51 (2), 187-193

Sotarauta, M. and R. Pulkkinen (2011), 'Institutional entrepreneurship for knowledge regions: In search of a fresh set of questions for regional innovation studies', Environment \& Planning C: Government and Policy, 29 (1), 96-112.

Vallance, P., M. Tewdwr-Jones and L. Kempton (2019), 'Facilitating spaces for place-based leadership in centralized governance systems: The case of Newcastle city futures', Regional Studies, 53 (12), 1723-1733.

Weick, K. E. (1993), 'The collapse of sensemaking in organizations: The Mann Gulch Disaster', Administrative Science Quarterly, 38, 628-652.

Zaleznik, A. (2004, January), 'Managers and leaders: Are they different?', Harvard Business Review, originally published in 1997. 